\title{
Anobothrus amourouxi sp. nov., a new species of Ampharetidae (Polychaeta) from the Capbreton Canyon (Bay of Biscay, NE Atlantic Ocean) - ERRATUM
}

\author{
PAULO BONIFÁCIO, NICOLAS LAVESQUE, GUY BACHELET AND JULIO PARAPAR
}

doi: 10.1017/So025315414002094, published by Cambridge University Press, 9 February 2015

The 'Key for Identification of the Species of the Genus Anobothrus in the World' has been corrected as follows:

1. No paleae...

- Paleae present

2. Modified notopodia with hirsute tips notochaetae

All notopodia without hirsute tips notochaetae

A. fimbriatus

A. apaleatus

3. 3 pairs of branchiae

4 pairs of branchiae.

4. Modified notopodia on TU8

- Modified notopodia on TU9.

A. flabelligerulus

5. Notochaetae present on fused segments II- III, prostomium Ampharete-type, branchiae forming transversal line

A. laubieri

- Notochaetae absent on fused segments II-III, prostomium conical, wide gap between groups of branchiae

A. dayi

6. Modified notopodia on TU6

Modified notopodia on $\mathrm{TU}_{7}$

A. bimaculatus

Modified notopodia on TU8 A. mancus

Modified notopodia on TU9.

A. paleatus

7. Circular band on TU1 A. patagonicus

- Circular band on TU2 (modified notochaetae without hirsute tips)

- Circular band on $\mathrm{TU}_{3}$

8. Paleae colourless, fine, with base slimmer than (or equal to) most developed notochaetae, outer pairs of branchiae distinctly narrower than inner, 12-13 AU .......A. wilhelmi - Paleae reddish, stout, with base stouter than most developed notochaetae, branchiae with almost the same diameter, $13 \mathrm{AU}$

A. rubropaleatus

9. Modified notopodia without notochaetae with hirsute tips ......................................................................................... 10

Only the modified notopodia with notochaetae with hirsute tips

.. 11

All notopodia with notochaetae with hirsute tips

A. gracilis

10. 3 teeth on uncini from $\mathrm{TU}_{1}$ (lateral view), paleae abruptly tapering to delicate tip A. pseudoampharete - 8 -9 teeth on uncini from TU1 (lateral view), diameter of all branchiophores more or less equal, less than 10 paleae, very conspicuous stout and long paleae ................. paleaodiscus 5 teeth on uncini from TU1 (lateral view), fourth pair of branchiophores two times slimmer and shorter than others reduced and their branchiostyles many times shorter than others, paleae longer than best-developed notochaeta, gradually tapering.............................. patersoni - 5 teeth on uncini from TU1 (lateral view), inner and middle pairs of branchiophores shorter and slimmer than others. A. mironovi

11. 6 teeth on uncini from TU1 (lateral view), surface of branchiostyle smooth, thoracic arrangement (fused SII-III with paleae from SII and without notochaetae from SIII)... A. glandularis

- 4-5 teeth on uncini from TU1 (lateral view), surface of all branchiostyles papillated, thoracic arrangement (fused SII-III with paleae from SII and notochaetae from SIII) ....

A. antarctica

6-7 teeth on uncini from TU1 (lateral view), surface of inner pair of branchiostyle with transversal ciliated ridges, thoracic arrangement (fused SII-III with paleae from SII and with reduced notopodia without notochaetae from SIII)........A. amourouxi sp. nov. 